\title{
Magdeleine of Martinique
}

\author{
George E. Gifford, Jr., M.D.
}

One of the first gifts to the Harvard Medical School was a wax model of a piebald negro girl, Magdeleine of Martinique. ${ }^{1}$ The Harvard Medical School, founded September 19, 1782, ${ }^{2}$ received the wax model on August 11, 1783, from Mr. Silas C. Brenton, a Boston merchant who was living in Martinique when the little girl was exhibited at a public show. The following letters accompanied the wax model.

Boston, August, 1783

Sir:

Mr. Silas C. Brenton wishes his compliments may be presented to the Corporation of Harvard College and begs their acceptance of the portrait of a child, which the bearer will deliver to you, all the history which can be obtain'd here shall be sent you tomorrow.

I am,

Sir,

your most obed. servant William Crafts

Ebenezer Stever Esq

From M.W ${ }^{m}$ Crafts, with a description of a figure in wax presented to the College by W. Silas Brenton representing a negro child in $\mathrm{S}^{t}$ Lucia

Ebenezer Stever Esq ${ }^{\text {re }}$

The history which was promised arrived at the Museum and it states:

This portrait was very exactly taken from a female child named Magdeleine. She was born in the Island of $\mathrm{S}^{t}$ Lucia in the month of January 1783 (1) of a black mother a native of the Island, who declares the father was an African slave, at her birth she was of the same colour as at the time this copy was taken, which was last May. The child was remarkably healthy when Mr. Silas C. Brenton saw her, who is a reputable merchant of this Country but has for several years resided at Martinico, where this child was brought, and exhibited as a public show. Mr. Brenton declares as great a likeness subsists between this portrait

Address for reprints: George E. Gifford, Jr., M.D., 15 Arden Road, Watertown, MA 02172.

\author{
From the Sections on Socio-Medical Sciences and \\ History of Medicine, \\ Boston University School of Medicine and the \\ Department of Psychiatry, Harvard Medical School, \\ Boston, Massachusetts
}

and the original as is possible between art and nature. The child before Mr. Brenton left the Island was purchas'd at an immense sum to carry to Europe as a curiosity of the human species.

August 15, 1783

The specimen remained in the Harvard Museum where it was seen by Professor Ralph Blanchard, Member of the Academy of Medicine and Past President of the French Society of the History of Medicine, in 1907. He was cordially received by Dr. William F. Whitney, who was then the Curator of the Warren Anatomical Museum. Blanchard reported that the wax model was exhibited under glass and that it was in good condition except for the fingers which had been damaged in a fall.

Blanchard described his Boston visit in a publication which appeared in the Bulletin of the French Society of the History of Medicine. The Warren Museum holds a reprint of that article inscribed by Blanchard to Dr. William F. Whitney: "Hommage reconnaissant et dévoné."

Blanchard suggested in his article that the man who executed the model was Le Masurier, the same man who also painted two portraits of the girl which hung in the Museum of Paris. Blanchard bemoaned the fact that Le Masurier was an able artist who was little noted or recognized.

A Biographical Dictionary of Wax Modellers was prepared by E. J. Pyke, published in 1973, concerned with wax models in general. ${ }^{3}$ The history of wax models in medicine was thoroughly reviewed by Thomas N. Haviland and Lawrence C. Parish in, "A Brief Account of the Use of Wax Models in the Study of Medicine." 4 


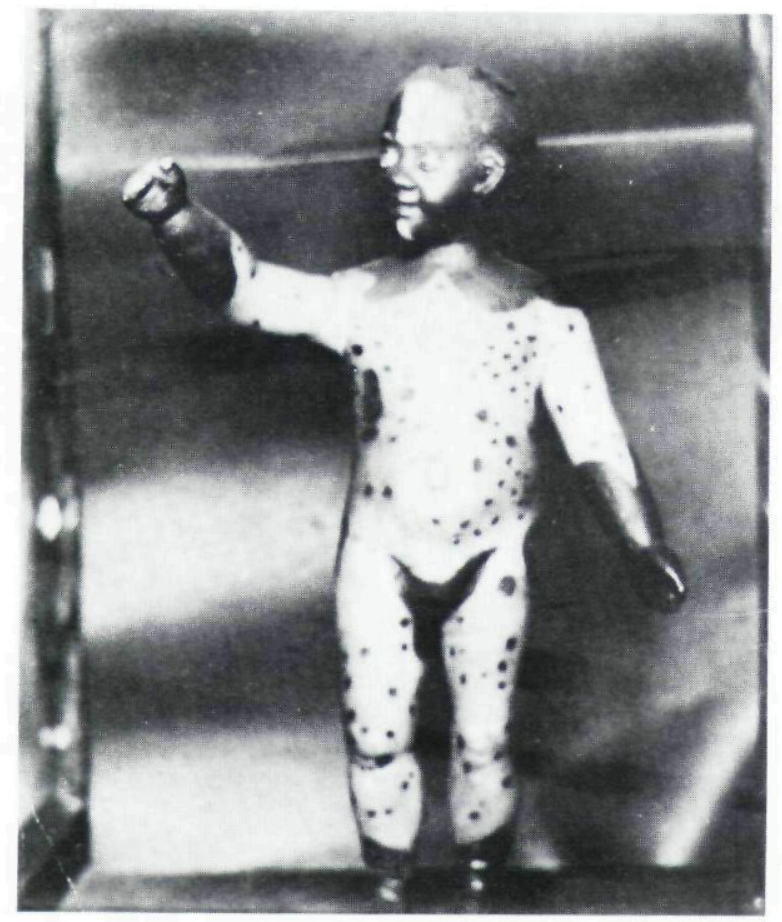

Figs. 1 and 2. Front and rear views of wax model.

One of the first written references to the use of medical wax models in the United States is cited in Mettler:

During the winter of 1774, Abraham Chovet (17041790), an Englishman who had been demonstrator to the barber-surgeons of London, in 1734, and author of, "A Syllabus of Index of the Parts that Enter into the Composition of the Human Body," London, 1732, came to Philadelphia from Jamaica. Chovet had a collection of wax models and dried and injected specimens, and late in 1774 , he inaugurated a course of lectures. These were so well attended that, in 1778, he erected an amphitheater on Water Street in Philadelphia.

John Adams also saw this anatomic collection and, in his diary (October 14, 1774) noted that Chovet's was more "exquisite and complete" than Shippen's

"Went in the morning to see Dr. Chovet and his skeletons and wax works - most admirable, exquisite representations of the whole animal economy. Four complete skeletons; a leg with all the nerves, veins and arteries injected with wax, two complete bodies in wax, full grown; waxen representations of all the muscles, tendons, \& c. of the head, brain, heart,

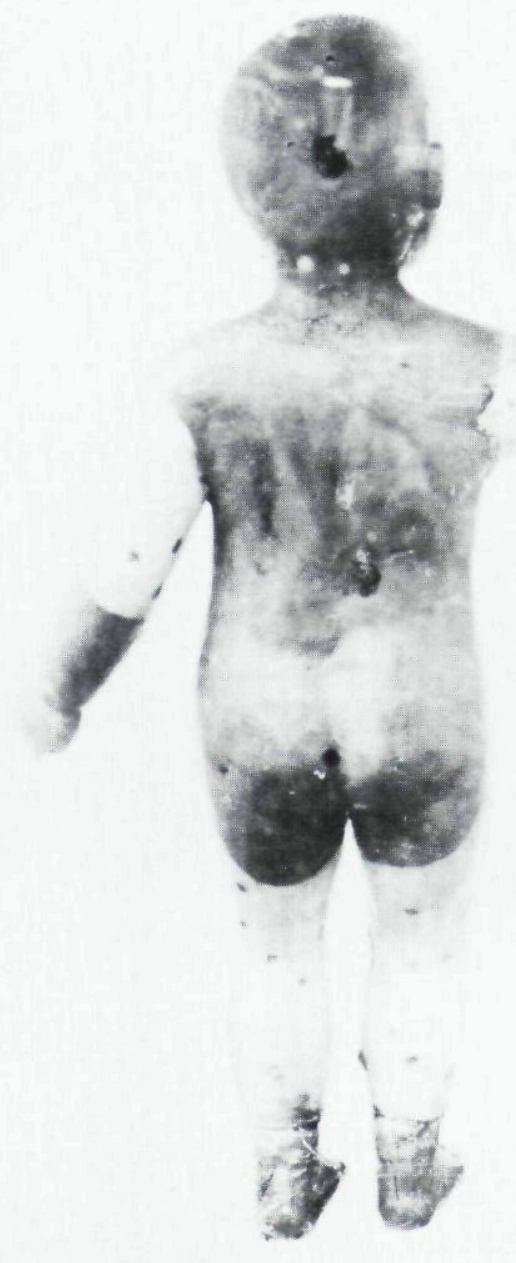

lungs, liver, stomach, \& c. This exhibition is much more exquisite than that of Dr. Shippen at the hospital. The Doctor reads lectures for two half joes a course, which takes up four months. These wax works are all of the Doctor's own hands."

Following Chovet's death his specimens were purchased by the Pennsylvania Hospital and ultimately formed part of the Wistar Collection. ${ }^{5}$

It would therefore seem most probable that the wax model at Harvard Medical School represents the first, or certainly one of the first, wax models held by a medical school in the United States.

In 1871, the first professorship of dermatology in the United States was created at Harvard Medical School; James Clarke White was appointed to the position. His lectures were "illustrated by photographs, wax models and specimens covering the entire field of dermatology." 2 Possibly, Magdeleine was among the specimens used by Professor White. Undoubtedly, Magdeleine was the oldest member of the Harvard Medical School's col- 
lection of wax models when Dr. Edward Wigglesworth donated his costly and valuable personal group to the University in 1873.

\section{Louis A. Duhring wrote in 1880:}

The year 1870 is, moreover, memorable for the arrival in Boston of a valuable dermatological museum, consisting of duplicates of the more important models on the Hospital St. Louis, Paris. The collection was purchased by Dr. Wigglesworth, and consists of many beautiful representations of disease from the hand of the well-known artist, M. Baretta. There are one hundred and seventy-nine models; of these one hundred and thirty-four portray non-syphilitic and forty-five syphilitic diseases of the skin. Among the rarer affectations, four examples of peculiar forms of scrofuloderma, six of lupus, three of lymphangitis, one of pityriasis rubra, and one of that most little understood disease called by the French mycosis fungoide, may be noted.

The last mentioned model shows the head, arm, and forearm, and anterior surface of the trunk, which regions are the seat of variously-sized, apparently soft, flat and prominently-raised, smooth and scaly, circumscribed and diffused, pinkish, fungoid tumors, tubercles, and shallow ulcers, the latter discharging a yellowish, sanious fluid. Some of these lesions are the size of coins, while others are as large as the palm of the hand. Over those which have not broken down numerous distinctly-defined, superficial capillary blood-vessels are conspicuous. The patient was a woman aged about 50 , but unfortunately there is no history. I have called special attention to this case because the subject of fungoid diseases of the skin is one of much interest, and moreover because it has occurred to me that the disease was probably the same as that which I brought before the Association at a former meeting, with the title "inflammatory fungoid neoplasm." 6

According to the article by Dr. Blanchard, Magdeleine, the piebald negro slave, was taken to France for exhibition and died of smallpox. However, David Gunner, the present curatorial associate of the Warren Anatomical Museum at Harvard Medical School, indicates that here is a long-standing legend that Magdeleine ended up in the court of Marie Antoinette. ${ }^{7}$ In the biographies of Marie Antoinette, there is no mention of Magdeleine; however, there is a pathetic little story that may possibly parallel that of Magdeleine.

No doubt Marie Antoinette had occasion to help and love many other children, the memory of whom is lost forever. We find her, for example, arranging at her own expense for the care of the three children of the Swiss Bersy, one of the attendants at the Petit Trianon when they got smallpox. The account reveals that the Queen even paid for a convalescence recommended by the doctors, on which their mother accompanied them. In 1787 , Chevalier de Boufflers, a great traveller, brought back to the Queen from Senegal a parrot .... and a young negro child. Instead of treating the black child as a little blackamoor, as was customary, and taking him into her service, Marie Antoinette had him baptized at Notre Dame de Versailles and gave him the christian names of Jean
Amilcar. Muller, one of the Queen's houseboys, was instructed to look after him. After the days of October, when revolutionary conditions made it difficult to find lodging for him at the Tuileries, Marie Antoinette had him placed in an institution for children at St. Cloud and made monthly payments for him up to August 10th through Monsieur de Salvert. When the monarchy fell and Marie Antoinette was made a prisoner in the Temple, nobody had the charity to look after the black child. Driven from the place where he boarded, he died of cold and hunger ${ }^{8}$

The word piebald is derived from two words; pie (magpie-a black and white bird) and bald (spotted with white). From a simple descriptive classification of the condition, it became recognized as hereditary. ${ }^{19}$ Today our understanding of the disease has evolved to a genetic, biochemical, and cytological formulation. ${ }^{10-12}$ At present piebaldism is explained in the following terms:

Decrease or absence of melanin pigmentation in mammalian skin may involve changes in one or more of four major biological processes of melanin metabolism: the formation, melanization, transfer, and degradation of melanosomes. In broad outline, the cellular and subcellular processes operative in a number of different kinds of hypermelanosis in man have been characterized by light and electron microscopy. In some cases, there exist experimental animals which express in approximate or identical form the same manifestation.

\section{More specifically:}

In our study of piebaldism, none of the four subjects showed at the light microscope level the presence of dopa-positive melanocytes in the hypomelanotic lesions of skin and hair. The electron microscope revealed a total absence of functioning melanocytes, except in one case in which only one melanocyte was found in the hypomelanotic lesion of the upper thigh. This melanocyte showed abnormal, unmelanized melanosomes that were spherical in overall shape and contained a granular interior. There were no melanized melanosomes. ${ }^{13}$

Geneticists continue an interest in the condition expressed by a dominant gene; they see mammalian analogues in Holstein cattle and black and tan dogs. ${ }^{14 *}$

The wax figure of Magdeleine remained at Harvard until several years ago when space needs led to the stor-

* In Stern's book, there is a plate on page 97 which is labeled:

"Fig. 53. White Spotting. Old engraving with inscription: 'The Spotted negro boy George Alexander Opattan, the spotted boy died on the 3 Febr 1813 aged 6 years, was buried at Great Marlow in Buckingham. ... Painted from life by Dan. Orme and engraved under his direction by his late pupil P. R. Cooper.' (Goldschmidt, Einfuhrung in die Vererbungslehre, 2nd ed. Engelmann, Leipzig, 1913. $)^{\prime \prime}$

Blanchard's article ${ }^{1}$ (Part III) also mentions this case; he gives the boy's name as George Alexander Gratton: he relates the history of the George Alexander case, pp 22-27. Blanchard had written previously in the Bulletin de la Medicine, Vol. V, pp 217-219, pl. II, 1906.

Blanchard says that George Alexander was born in the Antilles; one wonders if he and Magdeleine of Martinique were related? 
age of much of the Warren Museum Collection. Unfortunately, the temperature in the storage facility destroyed all of the heat-sensitive models and specimens. The wax statuette of the piebald girl was reduced to a tan amalgam of formless sludge. Fortunately, photographs of the wax model remain as a silent testament to the role of wax models for medical purposes and to the obvious sad fate of a victim of hereditary deformed cutaneous pigmentation-Magdeleine of Martinique.

\section{Acknowledgment}

Mrs. H. O. M. Merewether of London provided assistance; David Gunner, Curatorial Associate of the Warren Anatomical Museum, 25 Shattuck Street, Boston, MA 02115, loaned the reprints of the Blanchard and Keeler articles and photographs of the wax models; E. J. Pyke of London offered suggestions; Walter C. Quevado, Jr., of Brown University assisted with reprints, references; and Lawrence Charles Parish, Philadelphia, gave other helpful references.

\section{References}

1. Blanchard R: Nouvelles observations sur les Nègres-pies Geoffroy-Saint-Hilaire, à Lisbonne. Extrait Du Bulletin de la Societe francaise d'histoire de la Médecine, 1907, pp $16-22$
2. Beecher HK, Altschule MD: Medicine at Harvard: The First Three Hundred Years. Hanover, NH, The University Press of New England, 1977, pp 29, 126-127

3. Pyke EJ: A Biographical Dictionary of Wax Modellers. Oxford, Oxford University Press, 1973

4. Haviland TN, Parish LC: A brief account of the use of wax models in the study of medicine. I Hist Med 30:52, 1970

5. Mettler CC: History of Medicine. Toronto, Blakiston, 1947, p 88

6. Duhring LA: Transactions of the American Dermatological Association. Arch Dermatol 6:403, 1880

7. Gunner D: Personal communication

8. Huisman P, Jallut M: Marie Antoinette. London, Patrick Stephens, Ltd with Edita Lausanne, 1970, p 143

9. Keeler CE: The heredity of congenital white spotting in negroes. IAMA 103:179, 1934

10. Fitzpatrick TB, Quevedo WC Jr: Biological processes underlying melanin pigmentation and pigmentary disorters. In: Modern Trends in Dermatology 4. Edited by Borrie P, London, Butterworths, 1971, pp 122-149

11. Schaible RH: Comparative effects of piebald-spotting genes on clones of melanocytes in different vertebrate species. In: Pigmentation: Its Genesis and Biologic Control. Edited by Riley V New York, Appleton-Century-Crofts, 1972, pp 343-357

12. Davis BK, Verdol LD: Expansion and contraction of hypomelanotic areas in human piebaldism. Hum Genet 34:163, 1976

13. Jimbow K, Quevedo WC Jr, Fitzpatrick TB, Sugano H: Some animal models of human hypomelanotic disorders. Pigment Cell $3: 367,1976$

14. Stern C: Human Genetics, 2nd ed. San Francisco, WH Freeman \& Co, 1960, pp 96-97

\section{Diarrhea}

Known bacterial pathogens cannot be implicated in up to $75 \%$ of outbreaks of acute diarrhoeal disease. Nevertheless, until recently gastro-enteritis provided a poor hunting ground for virologists for, although such viruses as adenoviruses, echoviruses and Coxsackie viruses could be isolated from the stools of patients with acute gastro-enteritis, they could often be recovered with almost equal frequency from those without diarrhoeal disease, particularly in developing countries. However, the examination of negatively stained faecal preparations from patients with gastro-enteritis by electron microscopy has resulted in the discovery of many viruses, some of which, for example, rotaviruses and such parovirus-like viruses as the Norwalk agent, are undoubtedly the cause of acute gastroenteritis. The role of such other viruses as astroviruses, calciviruses, adenoviruses and coronaviruses remains as yet to be clearly established. In general, in vitro cultivation of viruses causing gastroenteritis in humans is either not possible or extremely difficult and of little value for routine diagnostic purposes but, since they are often excreted in very high titres, they may be detected without difficulty by electron microscopic examination of faecal extracts.-Banatvala JE: Viruses and Diarrhoes, Trans R Soc Trop Med Hyg 73:503, 1979. 
This document is a scanned copy of a printed document. No warranty is given about the accuracy of the copy. Users should refer to the original published version of the material. 